\title{
The carnivorous semi-slug Daudebardia brevipes (Gastropoda: Oxychilidae) in Belgium: an overlooked native species?
}

\author{
Louis Bronne ${ }^{1, *}$ \& Tom Van den Neucker ${ }^{2,3}$ \\ ${ }^{1}$ Natagora (NPO), Traverse des Muses 1, 5000 Namur, Belgium. \\ ${ }^{2}$ University of Antwerp, Department of Biology, Ecosystem Management Research Group, \\ Universiteitsplein 1C, 2160 Wilrijk, Belgium. \\ ${ }^{3}$ Biodiversity Inventory for Conservation NPO (BINCO), Walmersumstraat 44, \\ 3380 Glabbeek, Belgium. \\ *Corresponding author: louis.bronne@natagora.be
}

Keywords. Daudebardia brevipes, distribution, first record, Belgium, snail.

BRONNE L. \& VAN DEN NeUCKeR T. (2020). The carnivorous semi-slug Daudebardia brevipes (Gastropoda: Oxychilidae) in Belgium: an overlooked native species? Belgian Journal of Zoology 150: 197-202. https://doi.org/10.26496/bjz.2020.81

In this note we report the first record of the semi-slug Daudebardia brevipes (Draparnaud, 1805) from a natural environment in Belgium. On May $26^{\text {th }} 2020$, the first author found three adult individuals of D. brevipes on the premises of the Carrière de $\operatorname{Trooz}\left(50.5677^{\circ} \mathrm{N}, 5.7024^{\circ} \mathrm{E}\right)$, situated in the centre of the Province of Liège, Belgium. The survey of the quarry aimed at monitoring reptile and amphibian populations and was carried out in the context of the Life in Quarries project (Wallonia, 2015-2021; LIFE14 NAT/BE/000364). Carefully placed rubber mats and other objects that could serve as shelter for reptiles and amphibians were regularly lifted and checked. All three specimens of D. brevipes were found underneath a conveyor belt that was temporarily stored at the site and were partly hidden under a decaying tuft of grass. Other gastropods found underneath the same conveyor belt included Oxychilus navarricus helveticus (Blum, 1881), Arion vulgaris Moquin-Tandon, 1855 and Boettgerilla pallens Simroth, 1912. The conveyor belt was stored at about two meters from the tree line of a riparian woodland mainly composed of Salix alba, Acer pseudoplatanus, Alnus glutinosus and Betula pendula (Fig. 1). The woodland floor was littered with dead branches and the undergrowth consisted of Rubus sp., Clematis vitalba and a variety of herbs. The woodland is mainly situated on level ground, about three meters above the river Vesdre, on its north side. The steep banks of the Vesdre are mainly covered with Fallopia japonica. The following plants were found within a 3 meter radius around the conveyor belt: Acer pseudoplatanus, Alnus glutinosa, Brachypodium sylvaticum, Calamagrostis epigejos, Cirsium palustre, Epilobium parviflorum, Equisetum arvense, Eupatorium cannabinum, Fragaria vesca, Geum urbanum, Hypericum hirsutum, Hypericum perforatum, Origanum vulgare, Picris hieracioides, Rosa sp., Rubus sp. and Solanum dulcamara. No rocks are present on the ground in the direct vicinity of the conveyor belt. 


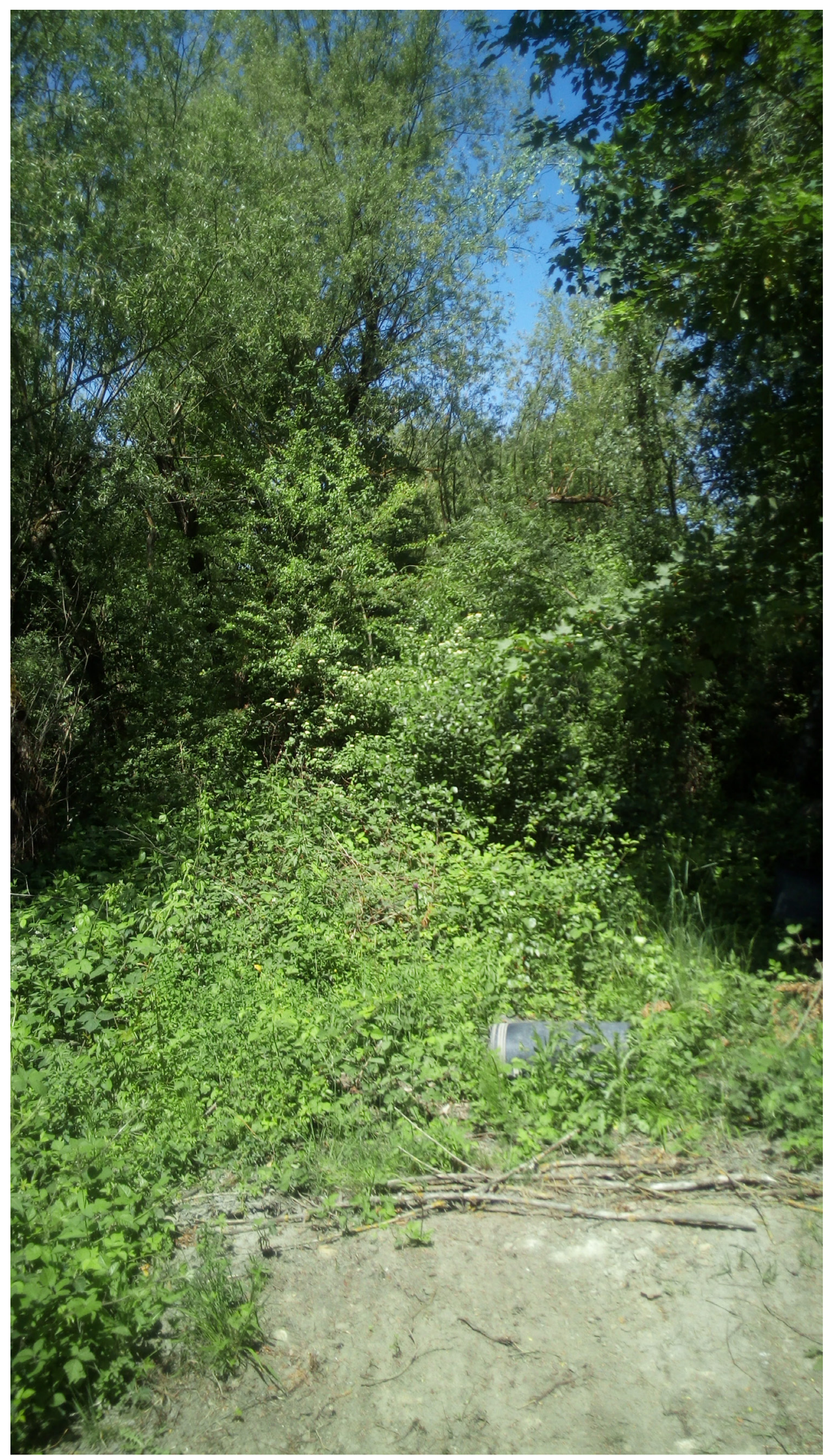

Fig. 1 - The site where the three individuals of Daudebardia brevipes (Draparnaud, 1805) were found. 
All three specimens found at Trooz fit the description of Daudebardia brevipes [1][2][3][4]. The stretched body of the largest specimen (Fig. 2) measured approximately $21 \mathrm{~mm}$ and its shell about $4.5 \mathrm{~mm}$, which are both within the ranges of measurements given in literature [1][2][3][4]. Other external characteristics of the three specimens found at Trooz were also in accordance with the descriptions given in the literature. The body was not retractable into the much smaller shell. The shell colour was yellowish, whereas the body colour was bluish-grey on the dorsal side and faded to off-white on the flanks and foot. The last whorl of the shell had a convex outer margin, giving it a more oval outline than the shell of its strongly resembling congener D. rufa (Draparnaud, 1805). The apical whorls were more closely coiled than in $D$. rufa and comprised a relatively smaller portion of the shell [1][2][3][4].

The known distribution of $D$. brevipes is scattered. The species occurs in parts of Central and Southern Europe. Its Central European range includes the east of France [5], parts of Germany, Luxembourg, Switzerland [3], Liechtenstein [6], Austria [7], Poland and the Ukraine close to the Polish border [8], the Czech Republic, Slovakia, Hungary, Romania [9], Bulgaria [10], Macedonia, Slovenia and Serbia [4]. In Southern Europe it is found in Albania, Bosnia and Herzegovina, Croatia [11], Montenegro, Greece and Italy [4]. The species is also mentioned from Turkey and Algeria [4]. Within its known range, D. brevipes prefers undisturbed primeval forests or scrubland in mountainous regions [2][4] [9][12][13]. In Central Europe, D. brevipes occurs in forests that mainly consist of Alnus, Quercus, Fagus, Abies or a combination of these genera [13][14][15], but predominantly in Alnus forests [4]. In southern Europe the species is mentioned from Pinus and Q. ilex forests [12]. Daudebardia brevipes requires deep soils, because it has a largely subterranean lifestyle [4]. It is considered to be a trogloxenic,

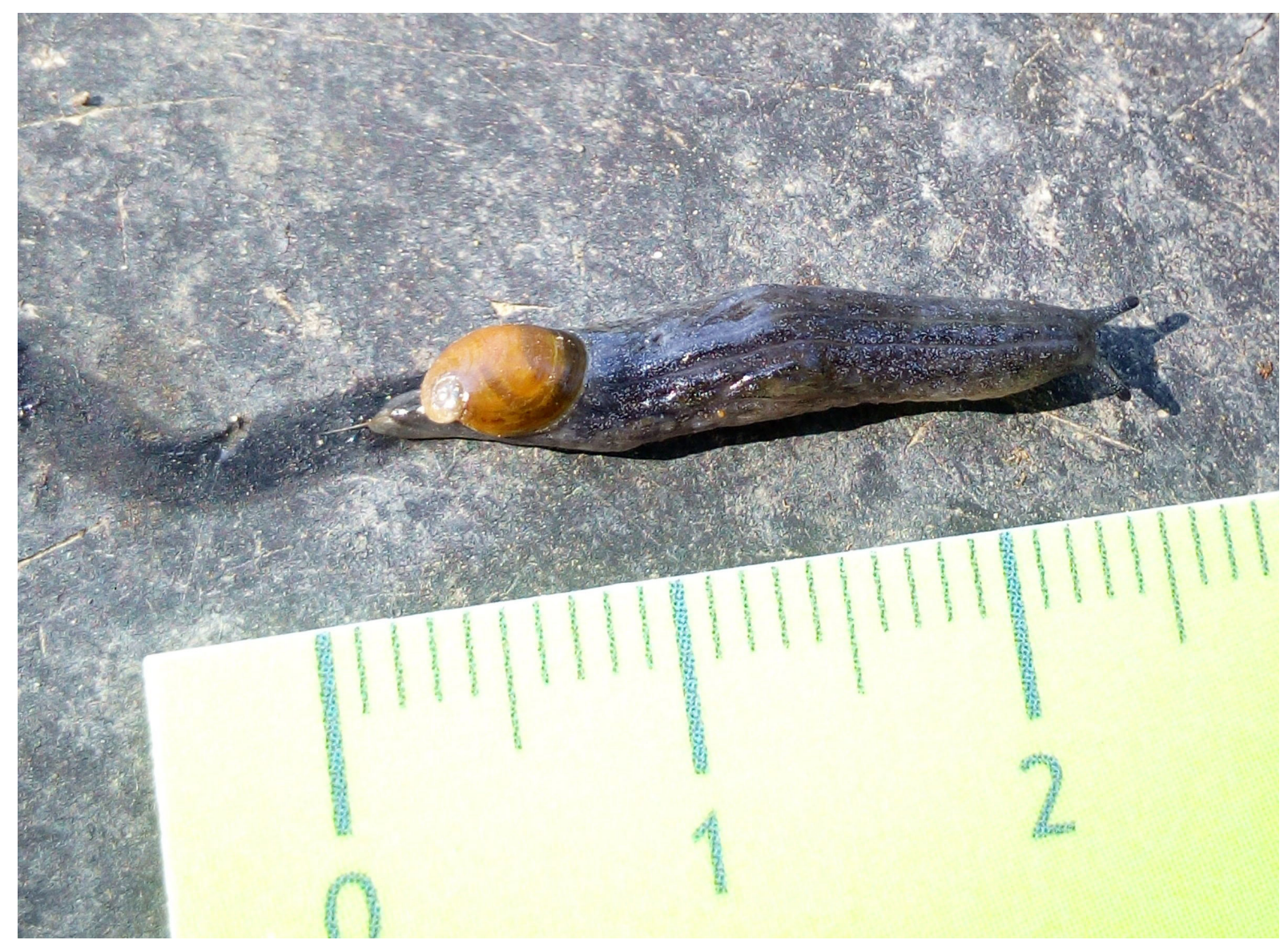

Fig. 2 - One of the three adults of Daudebardia brevipes (Draparnaud, 1805) found in Trooz. Scale bar is in $\mathrm{cm}$. 
(meso)hygrophilous and cold-resistant species [16]. The species is found in leaf litter and under stones in humid areas [2][9][13], sometimes in the vicinity of rock walls [12][17], where it feeds on earthworms, insect larvae and snails [4].

Interestingly, $D$. brevipes has recently been found in a greenhouse in Belgium, where it was likely introduced with foreign plant material [18]. However, the find of the three adult specimens in habitat that corresponds to habitats described in the literature for Central Europe may indicate that $D$. brevipes is a previously overlooked native species in Belgium. The following observations lead us to assume that a human-aided introduction is unlikely in Trooz. First, no vegetation seems to have been planted within the premises of the quarry on the side of the river where D. brevipes was found. Second, only little forestry activity has occurred in the vicinity of the quarry. Although the 400 meter stretch of the riparian woodland, where the individuals of D. brevipes were found, was sparsely covered by trees in 1971 [19], the deciduous tree forests on both sides of the woodland exist at least since the 1770s [20][21][22]. Hence, these forests could have served as refugia for a population of D. brevipes. Third, although huge quantities of soil are moved by the quarry activity, no foreign soil is imported into the area. Furthermore, Trooz is situated only about $50 \mathrm{~km}$ to the west of a known population of this rare - or largely overlooked - species in the Eifel (Germany). Fresh shells of D. brevipes (together with shells of the morphologically similar D. rufa) have been found in 2017 in the Eifel in a semi-natural floodplain forest and in a Fagus sylvatica forest near a wet clearcut of Picea abies (Pardey, pers. comm.). Still, it cannot be ruled out with absolute certainty that $D$. brevipes was introduced in Trooz by forestry operations further upstream along the Vesdre, considering the presence of the invasive Fallopia japonica on the river banks. Also, there are no fossil records of Daudebardia species from Belgium. Nonetheless, fossils of D. brevipes found in Dordogne (France), dated from 42000-33000 BP, show that the past range of the species reached further west than at present [23].

Daudebardia brevipes is considered a rare species throughout its range. On the Polish Red List it is categorized as vulnerable [24] and on the Red Lists of the Czech Republic, Switzerland, Austria and Germany it is categorized as endangered or critically endangered [3][17][25][26]. However, because of their hidden lifestyle, D. brevipes and other species of Daudebardia may easily be overlooked during surveys. For instance, a population of D. rufa has only recently been found in the UK, in 2016 [27], although the authors did express some uncertainty about whether it is an overlooked native species or an introduced species.

Further research should be undertaken - at least in the potentially suitable habitats of east Belgium to assess the status of $D$. brevipes. Meanwhile, the woodlands along the Vesdre should be cautiously considered as a unique refugium for the species in Belgium and as such should benefit from appropriate conservation measures to ensure its long-term survival.

\section{Acknowledgements}

We would like to thank Pascal Hauteclair and Rutger Barendse for the identification of plants, Valery Sitlivy for the translations from Ukrainian and the staff of the quarry for kindly allowing us access to the premises. Two anonymous reviewers and the editor are thanked for improving the manuscript.

\section{References}

1. RIEDEL A. (1967). Daudebardiinae (Gastropoda, Zonitidae) Bulgariens. Annales Zoologici 24 (8): 463-483. 
2. KERNEY M.P. \& CAMERON R.A.D. (1979). A Field Guide to the Land Snails of Britain and north-west Europe. Collins, London.

3. Boschi C. (2011). Die Schneckenfauna der Schweiz. Ein umfassendes Bild- und Bestimmungsbuch. Haupt, Bern/Stuttgart/Wien.

4. WeLTER-SCHULTES F.W. (2012). European non-marine Molluscs, a Guide for Species Identification. Planter Poster Editions, Göttingen.

5. BICHAIN J.M., GEISSERT F. \& BICHAIN J.M. (2003). Estimation de la richesse spécifique et de la valeur patrimoniale des mollusques du Parc Naturel Régional des Vosges du Nord. Documents malacologiques 4: $3-10$.

6. TRÜB H. (1988). Die Schnecken und Muscheln des Fürstentums Liechtenstein. Naturkundliche Forschung im Fürstentum Liechtenstein. Band 9. Regierung des Fürstentums Liechtenstein.

7. REISCHÜTZ A. \& REISCHÜTZ P.L. (2007). Rote Liste der Weichtiere (Mollusca) Österreichs. In: ZULKA K.P. (red.) Rote Listen gefährdeter Tiere Österreichs. Teil 2: Kriechtiere, Lurche, Fische, Nachtfalter, Weichtiere: 363-433. Grüne Reihe des Lebensministeriums 14/2.

8. GURAL-SVERVLOVA N.V. \& GURAL R.I. (2014). Rare and poorly-known gastropods (Gastropoda) of flat part of the western Ukraine. Studia Biologica 8: 255-272. https://doi.org/10.30970/sbi.0803.374

9. Grossu A.V. (1993). The catalogue of the molluscs from Romania. Travaux du Muséum national d'Histoire naturelle "Grigore Antipa" 33: 291-366.

10. IRIKOV A. \& ERÖSS Z. (2008). An updated and annotated checklist of Bulgarian terrestrial gastropods. Folia Malacologica 16: 199-207. https://doi.org/10.12657/folmal.016.015

11. ŠTAMOL V. (2010). Alist of the land snails (Mollusca: Gastropoda) of Croatia, with recommendations for their Croatian names. Natura Croatica 19: 1-76.

12. Ferreri D., Bodon M. \& MAnganelli G. (2005). Molluschi terrestri della provincia di Lecce. Thalassia Salentina 28: 31-130. https://doi.org/10.1285/i15910725v28p31

13. Georgiev D.G. (2005). Species diversity and habitat distribution of the Malacofauna (Mollusca: Bivalvia, Gastropoda) of Surnena Sredna Gora Mountain (Southern Bulgaria). In: GRUEV B., NIKOLOVA M. \& Donev A. (eds) Proceedings of the Balkan Scientific Conference of Biology in Plovdiv (Bulgaria) from 19th till 21 $1^{\text {st }}$ of May 2005: 428-435.

14. KAPPES H., Topp W., ZACH P. \& KULFAn J. (2006). Coarse woody debris, soil properties and snails (Mollusca: Gastropoda) in European primeval forests of different environmental conditions. European Journal of Soil Biology 42: 139-146. https://doi.org/10.1016/j.ejsobi.2005.12.003

15. ČILIAK M. \& ŠTefFeK J. (2011). Preliminary malacological survey of the site of community importance Kamenná Baba (Branisko - Bachureň). Folia faunistica Slovaca 16: 85-89.

16. IRIKOV A. \& Mollov I. (2015). Terrestrial gastropods (Mollusca, Gastropoda) of Strandzha Mountain and the Black Sea coast (Bulgaria and Turkey). Historia naturalis bulgarica 21: 13-48. https://doi.org/10.13140/RG.2.1.3908.0809

17. JUŘIČKOVÁ L. \& KUČERA T. (2005). Ruins of medieval castles as refuges for endangered species of molluscs. Journal of Molluscan Studies 71: 233-246. https://doi.org/10.1093/mollus/eyi031

18. VAn DEN Neucker T. \& SoORs J. (2019). The carnivorous semi-slug Daudebardia brevipes, a remarkable new greenhouse snail in the botanical garden of Ghent (Belgium) (Gastropoda, Oxychilidae). Spixiana 42: 192. 
19. ANONYMOUS (2016). Orthophotos 1971 [map]. Available from https://geoportail.wallonie.be/catalogue/3059d00d-9666-4a90-b606-88bbd861dd83.html [accessed 1 August 2020].

20. ANONYMOUS (2007). Cartes de Vandermaelen (1846-1854) [map].Available from https://geoportail.wallonie.be/catalogue/67ed5145-72be-499b-8a95-c94711f344f1.html [accessed 1 August 2020].

21. Anonymous (2010). Cartes de Ferraris (1770-1778) [map]. Available from https://geoportail.wallonie.be/catalogue/b8b9e555-a4d1-49bf-940d-31bbbf7613fc.html [accessed 1 August 2020].

22. AnOnYmous (2017). Carte du dépôt de la guerre (1865-1880) [map]. Available from https://geoportail.wallonie.be/catalogue/2005026d-c9e0-41c4-81f2-758ee21d47af.html [accessed 1 August 2020].

23. Preece R.C., Thorpe P.M. \& Robinson J.E. (1986). Confirmation of an interglacial age for the Condat tufa (Dordogne, France) from biostratigraphic and isotopic data. Journal of Quaternary Science 1: 57-65. https://doi.org/10.1002/jqs.3390010107

24. POKRYSZKO B.M. \& MALTZ T.K. (2007). Rare and endangered terrestrial gastropods of Lower Silesia (SW Poland) - current status and perspectives. Acta Universitatis Latviensis 723: 7-20.

25. SChNiEBS K., REISE H. \& BÖSSNECK U. (2006). Rote Liste Mollusken Sachsens. 2. überarbeitete Auflage. Sächsisches Landesamt für Umwelt und Geologie, Dresden.

26. Colling M., Klemm M., FAlKner G., Groh K., JungBluth J.H., NiederhöFer H.-J., RÄHLE W. \& SCHMID G. (2008). Rote Liste und Artenverzeichnis der Schnecken und Muscheln Baden-Württembergs. Zweite, neu bearbeitete Fassung. LUBW Landesanstalt für Umwelt, Messungen und Naturschutz BadenWürttemberg. Naturschutz-Praxis. Artenschutz 12. 185 pp. https://doi.org/10.4126/98-005095654

27. OWEN C., ROWSON B. \& WiLKINSON K. (2016). First record of the predatory semi-slug Daudebardia rufa (Draparnaud, 1805) from the UK (Eupulmonata: Daudebardiidae). Journal of Conchology 42: 119121.

Manuscript received: 17 September 2020

Manuscript accepted: 26 November 2020

Published on: 4 December 2020

Branch editor: Kurt Jordaens 